\title{
PENGARUH KEPEMIMPINAN TRANSFORMASIONAL TERHADAP KINERJA KARYAWAN BIDANG SUMBER DAYA INSANI (SDI) RUMAH SAKIT MUHAMMADIYAH BANDUNG
}

\author{
Rahmat Rusmayadi \\ Indra Sasangka \\ STIE Muhammadiyah Bandung \\ Jl. Karapitan No.143 Bandung
}

\begin{abstract}
Abstrak
Sumber daya manusia (SDM) merupakan aset yang sangat penting dalam suatu organisasi perusahaan, maka diperlukan suatu usaha untuk mengolah secara profesional agar terwujud suatu keseimbangan antara kebutuhan karyawan dengan keinginan tujuan perusahaan. Agar pencapaian tujuan perusahaan dapat dicapai diperlukan upaya, agar perusahaan mampu menciptakan situasi dan kondisi yang mendorong dan memungkinkan karyawan mengembangkan kemampuan dan keterampilan yang dimiliki secara optimal untuk meningkatkan kinerjanya.

Penelitian ini bertujuan untuk mengetahui pengaruh kepemimpinan transformasional terhadap kinerja karyawan bidang sumber daya insani pada Rumah Sakit Muhammadiyah Bandung. Variabel dependen dalam penelitian ini adalah kinerja karyawan, sedangkan variabel independen dalam penelitian ini adalah kepemimpinan transformasional.

Metode penelitian yang digunakan adalah metode analisi deskriptife verifikatif. Penelitian ini dilakukan di Rumah Sakit Muhammadiyah Bandung dengan populasi karyawan bidang sumber daya insani yang berjumlah 32 orang. Sampel dalam penelitian ini berjumlah 32 orang karyawan karena merupakan sampel jenuh. Teknik pengumpulan data dilakukan dengan metode kuesioner (Angket). Uji validitas dan realibilitas data formula korelasi Cronvabch's alpha. Teknik analisis data yang digunakan, Regresi linier sederhana dan koefisien determinasi.

Berdasarkan hasil analisis data dapat diambil kesimpulan bahwa ada pengaruh yang sangat signifikan Kepemimpinan Transformasional terhadap kinerja karyawan bidang sumber daya insani pada Rumah Sakit Muhammadiyah Bandung.
\end{abstract}

Kata Kunci: Kepemimpinan Transformasional dan Kinerja Karyawan.

\section{PENDAHULUAN}

Rumah Sakit adalah bentuk perusahaan atau organisasi yang mana sebagai tempat pelayanan kesehatan bagi masyarakat luas. Sebagaimana yang termaktub dalam Undang Undang
Republik Indonesia Nomor 44 Tahun 2009 tentang Rumah Sakit Bab I Ketentuan Umum Pasal 1 poin 1 menyebutkan bahwa "Rumah sakit adalah institusi pelayanan kesehatan yang menyelenggarakan pelayanan 
kesehatan perorangan secara paripurna yang menyediakan pelayanan rawat inap, rawat jalan, dan gawat darurat".

Merujuk kepada bunyi Undang Undang Republik Indonesia Nomor 44 Tahun 2009 tersebut diatas, maka Rumah Sakit itu ialah dalam bentuk institusi, lembaga, perusahaan dan organisasi yang beroperasi untuk memberikan pelayanan dibidang kesehatan. Pada berbagai bidang khususnya kehidupan berorganisasi, faktor manusia merupakan masalah utama disetiap kegiatan yang ada didalamnya. Kepemimpinan adalah suatu seni atau tata cara dalam manajemen, mengelola sekelompok orang atau dalam kontek organisasi untuk memberikan "arahan" demi mencapai tujuan secara bersama-sama.

Dalam proses memberikan pelayanan hal tersebut ada peran dan fungsi pemimpin dalam memberikan pengaruh terhadap kinerja karyawan. Survei lain yang dilakukan oleh sebuah consulting firm global juga menyatakan bahwa naik turunnya iklim kerja sebesar $70 \%$ dipengaruhi oleh gaya kepemimpinan, dan kemudian naik turunnya kinerja sebesar $30 \%$ dipengaruhi oleh iklim kerja. Jadi, jika mau memperbaiki kinerja 30\% lebih tinggi, cukup dengan memperbaiki iklim kerja, dan gaya kepemimpinan (dengan catatan faktor-faktor lain dianggap tetap atau stabil). (http//www.portalhr.com diakses tanggal 24 Februari 2016)

Kepemimpinan (leadership) dapat dikatakan sebagai cara dari seorang pemimpin (leader) dalam mengarahkan, mendorong dan mengatur seluruh unsur-unsur di dalam kelompok atau organisasinya untuk mencapai suatu tujuan organisasi yang diinginkan sehingga menghasilkan kinerja pegawai yang maksimal. Dengan meningkatnya kinerja pegawai berarti tercapainya hasil kerja seseorang atau pegawai dalam mewujudkan tujuan organisasi.

Kualitas manusia sebagai tenaga kerja merupakan modal dasar dalam masa pembangunan. Tenaga kerja yang berkualitas akan menghasilkan suatu hasil kerja yang optimal sesuai dengan target kerjanya. Manusia sebagai tenaga kerja atau karyawan merupakan sumberdaya yang penting bagi perusahaan, karena mereka mempunyai bakat, tenaga dan kreatifitas yang dibutuhkan oleh perusahaan untuk mencapai tujuannya.

Sumber daya manusia (SDM) merupakan aset yang sangat penting dalam suatu organisasi perusahaan, maka diperlukan suatu usaha untuk megolah secara profesional agar terwujud suatu keseimbangan antara kebutuhan karyawan dengan keinginan dan tujuan perusahaan. Agar pencapaian tujuan perusahaan dapat dicapai diperlukan upaya, agar perusahaan mampu menciptakan situasi dan kondisi yang mendorong dan memungkinkan karyawan mengembangkan kemampuan dan ketrampilan yang dimiliki secara optimal untuk meningkatkan kinerjanya.

Peranan pimpinan sangatlah besar bagi keberhasilan perusahaan dalam mencapai tujuan. Dari merekalah muncul gagasan-gagasan baru dan inovatif dalam pengembangan perusahaan. Namun tidak dapat dipungkiri bawahan mereka juga memiliki peranan yang tidak kalah penting, karena bawahan inilah yang akan menjalankan dan melaksanakan gagasan pimpinan yang tertuang dalam setiap 
keputusan. Baik tidaknya bawahan melaksanakan tugas mereka tergantung dari pimpinan itu sendiri. Bagaimana seorang pemimpin memberikan pengaruh dan motivasi untuk mempengaruhi para bawahnya melakukan berbagi tindakan sesuai dengan yang diharapkan.

Salah satu permasalahan yang terjadi dirumah sakit Muhammadiyah Bandung seiring dengan peralihan masa jabatan pemimpin (Wakil Direktur), dalam jangka waktu dua tahun perjalanan seorang pemimpin / atasan telah mempengaruhi karyawannya dengan berbagai indikasi kearah kepemimpinan transformasional seperti menggunakan pengaruh ideal dengan menunjukkan kharisma yang dimilikinya, dan pertimbangan individual dengan mengenali dan mengerti kebutuhan serta kemampuan bawahannya, sedangkan stimulasi intelektual kadang - kadang ditunjukkan dengan mengajak bawahan berdiskusi untuk menyelesaikan suatu persoalan dalam rapat yang biasanya dilaksanakannya, inspirasi yang memotivasi ditunjukkan dengan cara penyampaian visi dan tujuan yang menarik sehingga bawahan termotivasi untuk melakukan instruksi dari atasannya, sedangkan penilaian kinerja karyawan lebih banyak berdasarkan prestasi kerja, kerajinan kerja. Akan tetapi dalam hal kinerja karyawan terdapat masalah yang akan coba peneliti gambarkan dari hasil wawancara, peneliti mendapakan data tentang kinerja karyawan yang dimana narasumbernya sebanyak 8 orang. Adapun hasilnya sebagai berikut:

Tabel 1. Hasil Wawancara tentang Kinerja Karyawan

\begin{tabular}{|c|l|c|}
\hline 1 & $\begin{array}{l}\text { Karyawan tidak mengalami pengembangan } \\
\text { wawasan keilmuan. }\end{array}$ & 2 orang \\
\hline 2 & $\begin{array}{l}\text { Kurangnya Penghargaan terhadap } \\
\text { Karyawan. }\end{array}$ & 2 orang \\
\hline 3 & $\begin{array}{l}\text { Tidak terbangunnya kerjasama yang baik } \\
\text { antar karyawan. }\end{array}$ & 2 reponden \\
\hline 4 & $\begin{array}{l}\text { Tidak terbangunnya Integritas personal } \\
\text { yang baik. }\end{array}$ & 2 responden \\
\hline
\end{tabular}

\section{KERANGKA TEORITIS \& HIPOTESIS \\ Konsep Kinerja Karyawan Kinerja}

Bernardin dan Russel (dalam Ruky, 2001:15) memberikan pengertian performance atau kinerja sebagai berikut :Performance is defined as the record of outcomes produced on a specified job function or activity during time period". Prestasi atau kinerja adalah catatan tentang hasil-hasil yang diperoleh dari fungsifungsi pekerjaan tertentu atau kegiatan selama kurun waktu tertentu.

Menurut Ruky (2002:16) kinerja adalah "hasil yang dicapai dari suatu pekerjaan dan kontribusinya terhadap organisasi". Dari pernyataan tentang kinerja dapat disimpulkan bahwa kinerja adalah hasil kerja yang dicapai seseorang dalam melaksanakan tugas yang dibebankan terhadap karyawan.

Meiner (dalam As'ad, 2000:7), job performance diartikan sebagai kesuksesan seseorang dalam melaksanakan suatu pekerjaan (As'ad, 2000:7). Berdasarkan pengertian tersebut job performance dapat diartikan sebagai hasil yang dicapai seseorang menurut ukuran yang berlaku untuk pekerjaan yang bersangkutan.

\begin{tabular}{|l|l|l|}
\hline No & Uraian & Narasumber \\
\hline
\end{tabular}




\section{Jenis Kinerja Karyawan}

Menurut Prawirosentono (1999

: 140-142) jenis kinerja ada 3, yaitu :

1. Kinerja administratif

Berkaitan dengan kinerja dari mekanisme aliran informasi antar unit kerja dalam perusahaan agar tercapai sinkronisasi kerja.

2. Kinerja operasional

Berkaitan dengan efektivitas penggunaan setiap sumber daya yang digunakan perusahaan di dalam menghasilkan produk yang direncanakan baik kuantitas maupun kualitasnya.

3. Kinerja strategik

Berkaitan dengan ketepatan memilih strategi yang akan digunakan di dalam menghadap perusahaan-perusahaan pesaing. Pada umumnya kebijakan strategik dipegang oleh pimpinan perusahaan. Kinerja pimpinan perusahaan dalam menetukan strategi dipengaruhi pula oleh kinerja karyawan unit-unit kerja yang mendukung.

\section{Faktor-Faktor Yang Mempengaruhi Kinerja}

Menurut Gibson, Ivanchevich dan Donelly (1992: 52), tiga variabel yang mempengaruhi perilaku dan kinerja adalah :

1. Variabel individu terdiri dari :
a. kemampuan, ketrampilan - mental dan fisik
b. latar belakang yang terdiri dari keluarga dekat, tingkat sosial, dan pengalaman
c. demografis meliputi umur asal usul dan jenis kelamin.

2. Variabel organisasi,
a. meliputi sumber daya
b. kepemimpinan
c. imbalan
d. struktur organisasi
e. dan desain pekerjaan.

3. Variabel psikologis
a. meliputi persepsi,
b. sikap,
c. kepribadian,
d. perilaku,
e. motivasi dan lainnya.

\section{Penilaian Kinerja}

Menurut Gomes (2003:142), variabel yang digunakan untuk menilai perilaku dan kinerja adalah :

1. Kuantitas kerja : Jumlah kerja yang dilakukan dalam suatu periode waktu yang ditentukan.

2. Kualitas kerja : Kualitas kerja yang dicapai berdasarkan syarat-syarat kesesuaian dan kesiapannya.

3. Jobknowledge : Luasnya pengetahuan mengenai pekerjaan dan ketrampilannya.

4. Kreatifitas : Keaslian gagasangagasan yang dimunculkan dan tindakan-tindakan untuk menyelesaikan persoalanpersoalan yang timbul.

5. Kerjasama : Kesediaan untuk bekerjasama dengan orang lain (sesama anggota organisasi.

6. Dependability : Kesadaran dan dapat dipercaya dalam hal kehadiran dan penyelesaian kerja.

7. Inisiatif : Semangat untuk melaksanakan tugas-tugas baru dan dalam memperbesar tanggungjawabnya.

8. Kualitas personal : Menyangkut kepribadian, kepemimpinan, 
keramah-tamahan dan integritas pribadi.

\section{Metode Penilaian Kinerja Karyawan}

Dessler (1998:29) menyebutkan empat pendekatan penilaian kinerja untuk pegawai bawahan, yaitu penilaian oleh supervisor terdekat/langsung, penilaian oleh teman sekerja, komite penilaian, dan penilaian diri (se/l assesmenf).

1. Penilaian oleh supervisor langsung

Penilaian supervisor merupakan jantung dari seluruh sistem penilaian uraumnya. Hal mi disebabkan karena mudah untuk memperoleh hasil penilaian supervisor dan dapat diterima oleh akal sehat. Para supervisor merupakan orang yang tepat untuk mengamati dan menilai- prestasi bawahannya. Oleh sebab itu, seluruh sistem penilaian umumnya sangat tergantung pada evaluasi yang dilakukan o!eh supervisor. Pada penelitian ini pendekatan penilaian oleh atasan/supervisor langsung yang akan digunakan.

2. Penilaian teman sekerja

Penilaian seorang pegawai oleh teman kerjanya telah terbukti efektif dalam memperkirakan

keberhasilan manajemen di masa depan.

3. Panitia/Komite penilai

$\begin{array}{lr}\begin{array}{l}\text { Banyak } \\ \text { nienggunakan }\end{array} & \text { perusahaan } \\ \text { panitia/komite } & \text { untuk } \\ \text { menilai para } & \text { pegawai. }\end{array}$

Panitia ini beranggotakan para supervisor langsung dan 3 atau 4 anggota adalah supervisor lain, seliap anggota panitia seharusnya mampu menilai prestasi pegawai dengan baik.

4. Penilaian diri

Beberapa perusahaan telah berpengalaman menerapkan pengharkatan prestasi yang dilakukan oleh pegawai sendiri. Tetapi hal ini umumnya bukanlah pilihan yang direkomendasikan. Masalahnya adalah hampir seluruh studi menunjukkan bahwa para pegawai umumnya menilai diri mereka lebih tinggi dari penilaian supervisor atau teman sekerja mereka Oleh karena itu para supervisor yang meminta pegawai mereka untuk menilai prestasi mereka sendiri hendaknya diperingatkan bahwa hasil penilaian diri mungkin jauh berbeda dengan penilaian atasan atau rekan kerja.

\section{Manfaat Penilaian Kinerja Karyawan}

Mengenai manfaat penilaian kinerja, Handoko (1999) mengemukakan:

1. Perbaikan prestasi kerja atau kinerja.

Umpan balik pelaksanaan kerja memungkinkan karyawan, manajer dan departemen personalia dapat memperbaiki kegiatan-kegiatan mereka 
untuk meningkatkan prestasi.

2. Penyesuaian-penyesuaian kompensasi.

Evaluasi prestasi keja membantu para pengambil keputusan dalam mcnentukan kenaikan upah, pemberian bonus dan bentuk kompensasi lainnya.

3. Keputusan-keputusan penempatan.

Promosi dan transfer biasanya didasarkan atas prestasi kerja atau kinerja masa lalu atau antisipasinya.

4. Perencanaan kebutuhan latihan dan pengembangan.

Prestasi kerja atau kinerja yang jelek mungkin menunjukkan perlunya latihan. Demikian pula sebaliknya, kinerja yang baik mungkin mencerminkan potensi yang harus dikembangkan.

5. Perencanaan dan pengembangan karir.

Umpan balik prestasi mengarahkan keputusankeputusan karir, yaitu tentang jalur karir tertentu yang harus diteliti.

6. Mendeteksi penyimpangan proses staffing.

Prestasi kerja yang baik atau buruk adaiah mencerminkan kekuatan atau kelemahan prosedur staffing departemen personalia.

7. Melihat ketidakakuratan informasional.

Prestasi kerja yang jelek mungkin menunjukkan kesalahan-kesalahan dalam informasi analisis jabatan, rencana sumber daya manusia, atau komponen komponen lain system informasi manajemcn personalia.

Menggantungkan pada informasi yang tidak akurat dapat menyebabkan keputusan-keputusan personalia tidak tepat.

8. Mendeteksi kesalahankesalahan desain pekerjaan.

Prestasi kerja yang jelek mungkin merupakan tanda kesalahan dalam desain pekerjaan. Penilaian prestasi membantu diagnosa kesalahan-kesalahan tersebut.

9. Menjamin kesempatan kerja yang adil.

Penilaian prestasi kerja yang akurat akan menjamin keputusan-keputusan penempatan internal diambil tanpa diskriminasi.

10. Melihat tantangan-tantangan ekternal.

Kadang-kadang prestasi seseorang dipengaruhi oleh faktor-faktor diluar lingkungan kerja, seperti keluarga, kesehatan, dan masalah-masalah pribadi lainnya.

\section{Kepemimpinan \\ Pengertian Kepemimpinan}

Kepemimpinan menurut Hempill \& Coons (dalam Yukl 2005:4) adalah "perilaku individu yang mengarahkan aktivitas kelompok untuk mencapai sasaran bersama".

Sedangkan menurut Rauch \& Behling (dalam Yukl 2005:4) adalah "Proses mempengaruhi aktivitas 
kelompok yang teroganisir untuk mencapai sasaran". Definisi ini menunjukkan bahwa kepemimpinan menggunakan pengaruh yang ditujukan pada peningkatan kemampuan bawahan (karyawan).

Sementara itu Certo dalam Ismail (2007:12) mendefinisikan kepemimpinan sebagai proses mengarahkan perilaku orang lain ke arah pencapaian beberapa tujuan. Pengarahan dalam hal ini adalah cara cara yang dipergunakan agar orang lain mau bertindak dalam suatu cara tertentu atau mengikuti cara tertentu yang telah ditetapkan untuk mencapai tujuan. Dari definisi kepemimpinan yang telah diuraikan maka dapat disimpulkan bahwa kepemimpinan adalah suatu cara atau kemampuan seorang pemimpin menggunakan pengaruhnya. Dalam hal ini adalah pengaruh yang sengaja terhadap orang lain untuk menstruktur aktivitass aktivitas dalam sebuah kelompok atau organisasi untuk mencapai tujuan organisasi melalui hubungan yang baik dengan bawahan.

\section{Jenis - Jenis Kepemimpinan}

Ada beberapa jenis kepemimpinan, diantaranya ialah sebagai berikut:

\section{Kepemimpinan Karismatik} Konsep kharismatik (charismatic) atau kharisma (charisma) menurut Weber (1947) lebih ditekankan kepada kemampuan pemimpin yang memiliki kekuatan luarbiasa dan mistis. Menurutnya, ada lima faktor yang muncul bersamaan dengan kekuasaan yang kharismatik, yaitu : Adanya seseorang yang memiliki bakat yang luarbiasa, adanya krisis sosial, adanya sejumlah ide yang radikal untuk memecahkan krisis tersebut, adanya sejumlah pengikut yang percaya bahwa seseorang itu memiliki kemampuan luarbiasa yang bersifat transendental dan supranatural, serta adanya bukti yang berulang bahwa apa yang dilakukan itu mengalami kesuksesan.

\section{Kepemimpinan}

\section{Transformasional}

Kirkbride

memberikan

pengertian bahwa kepemimpinan transformasional merupakan suatu usaha pemimpin mempengaruhi bawahannya dengan keterbukaan dan penyampaian visi yang jelas, membentuk komitmen pekerja melalui identifikasi dan perlibatan personal.

Adapun dalam penelitian ini penulis menggunakan jenis kepemimpinan transformasional sebagai variable $\mathrm{X}$.

\section{Kepemimpinan Transformasional}

Formulasi asli dari teori kepemimpinan transformasional meliputi tiga jenis perilaku (Bass, 1985 dalam Yukl , 2005 : 305), yakni :

1. Pengaruh ideal / kharisma

2. Stimulasi Intelektual

3. Pertimbangan Indvidual

Sebuah revisi dari teori tersebut oleh Bass \& Avolio pada tahun 1990 telah menambahkan Perilaku Pemimpin Transformasional yang disebut "motivasi inspirasional".

Sedangkan menurut Bartram dan Casimir (2006:5) kepemimpinan transformational merupakan kepemimpinan yang memberikan penjelasan visi bagi bawahan, bersifat rela berkorban demi kepentingan organisasi, memotivasi bawahan, dan menunjukkan kepedulian terhadap tiap individu bawahan, sedangkan Kirkbride memberikan pengertian bahwa kepemimpinan transformasional merupakan suatu usaha pemimpin 
mempengaruhi bawahannya dengan keterbukaan dan penyampaian visi yang jelas, membentuk komitmen pekerja melalui identifikasi dan perlibatan personal.

Dapat disimpulkan bahwa kepemimpinan transformasional merupakan suatu cara pemimpin mempengaruhi bawahan melalui penjelasan visi yang jelas, bersifat rela berkorban demi kepentingan organisasi, memotivasi , dan menunjukkan kepedulian terhadap tiap individu bawahan dalam organisasi . Sehingga para bawahan merasakan kepercayaan, kebanggan dan keberadaanya diakui dalam perusahaan.

\section{Dimensi}

\section{Transformasional}

\section{A. Pengaruh Ideal / Kharisma}

\section{Pengertian}

Menurut Kirkbride (2006 : 27), pengaruh ideal / kharisma merupakan perilaku pemimpin dimana ia menjadi 'role model' bagi mereka yang ada disekelilingnya. Pemimpin yang demikian mampu menjadi role model karena mereka memiliki karakteristik personal tertentu atau 'kharisma' atau karena mereka menunjukkan semangat tertentu. Pemimpin tersebut seringkali terlihat tinggi dalam moralitas, kepercayaan, integritas, kejujuran, dan tujuan, sedangkan Yukl (2005:305) memberi pengertian pengaruh ideal adalah perilaku yang membangkitkan emosi dan identifikasi yang kuat dari pengikut terhadap pemimpin Melalui pengaruh seperti itu, para bawahan akan menaruh respek, rasa kagum dan percaya pada pimpinannya.

Pemimpin transformasional yang memilki perilaku pengaruh ideal atau menunjukkan karismanya mempunyai tiga karakter (Luthans, 1992 :283), yaitu :

1. Adanya kepercayaan diri yang tinggi

2. Sifat dominan terhadap bawahan

3. Keyakinan yang kuat terhadap visi dan kemampuan untuk menyampaikan visi.

Berdasarkan pendapat ini , pemimpin yang memiliki pengaruh ideal adalah pemimpin yang memilki kemampuan lebih di mata bawahannya yang berupa rasa percaya diri yang sangat tinggi, sifat dominan terhadapa bawahan, keyakinan yang kuat terhadap visi dan kemampuan untuk menyampaikannya, sehingga pemimpin mampu mempengaruhi bawahannya dengan sifat - sifat yang dimiliki seperti itu.

2. Indikator Pengaruh Ideal Menurut Kirkbride (2006 :27), indikator kunci dari perilaku pengaruh ideal adalah :

1. Mendemonstrasikan kompetensi tertentu

2. Merayakan keberhasilan bawahan

3. Menyadari adanya krisis lebih cepat

4. Menggunakan kekuatan untuk hal positif

\section{B. Stimulasi Intelektual}

\section{Pengertian}

Menurut Kirkbride (2006:26), stimulasi intelektual adalah perilaku pemimpin yang menstimuli atau merangsang bawahan untuk berpikir atas suatu masalah untuk mereka dan mengembangkan kemampuan bawahannya untuk menyelesaikan suatu masalah, sedangkan Yukl (2005:305) memberi pengertian stimulasi intelektual adalah perilaku 
yang meningkatkan kesadaran para bawahan akan permasalahan yang terjadi mempengaruhi pengikut untuk memandang masalah dari prespektif yang baru. Dengan kata lain stimulasi intelektual merupakan praktek kepemimpinan dimana pemimpin merangsang bawahan agar selalu kritis terhadap kondisi yang ada.

2. Indikator Stimulasi Intelektual Menurut Kirkbride (2006 :26), indikator kunci dari perilaku kepemimpinan ini adalah :

1. Mengenali pola yang sulit untuk dibayangkan

2. Bersedia mengedepankan suatu ide dari bawahan

3. Mendorong bawahan untuk mengkaji ulang suatu masalah

4. Menciptakan kesiapan untuk mengubah cara berpikir

\section{Pertimbangan Indvidual}

1. Pengertian

Menurut Kirkbride (2006:26), pertimbangan individual merupakan perilaku utama dari Perilaku Pemimpin Transformasional karena perilaku ini menunjukkan kepedulian pemimpin terhadap bawahan, memperlakukan bawahan sebagai individu yang sama, dan mendengarkan ide mereka, sedangkan Yukl (2005:305) memberi pengertian pertimbangan individual adalah suatu pemberian dukungan, dorongan dan pelatihan dari pemimpin kepada pengikut.

2. Indikator Individual

Menurut Kirkbride (2006 :26) Indikator kunci dari Pertimbangan individual adalah :

1. Mengenali perbedaan antar bawahan pada kekuatan dan kelemahan mereka, pada apa yang mereka suka dan apa yang mereka benci

2. Merupakan pendengar aktif

3. Melaksanakan proyek berdasarkan kemampuan dan kebutuhan individu

4. Mendukung dengan pandangan dua arah

5. Mempromosikan pengembangan diri

\section{Inspirasi Motivasional}

1. Pengertian

Menurut Kirkbride (2006:26), inspirasi motivasional adalah peemimpin yang memiliki kemampuan untuk memotivasi bawahan untuk meningkatkan kinerja dan mampu menjelaskan dan menggambarkan visi secara jelas dengan cara yang benar sehingga bawahan mampu menerima visi tersebut dan berjuang dengan visi tersebut.

Menurut Yukl (2005:305) inspirasi motivasional merupakan suatu usaha seorang pemimpin mempengaruhi bawahannya dengan cara penyampaian visi yang menarik serta dengan menggunakan simbol untuk memfokuskan upaya bawahan, sehingga dapat dikatakan bahwa

Pemimpin yang beperilaku motivasi inspirasional adalah pemimpin yang mampu memberikan inspirasi dan motivasi para bawahannya untuk mengatasi berbagai krisis dan tantangan. Pemimpin seperti ini cenderung mampu mampu menjelaskan dan menggambarkan visi secara jelas dengan cara yang benar sehingga bawahan mampu menerima visi tersebut dan berjuang dengan visi tersebut. Pemimpin yang demikian juga sering sukses dalam meningkatkan ekspektasi bawahan sehingga mereka bisa mencapai apa yang mereka kira tidak bisa mereka capai. 
2. Indikator Dari Inspirasi Motivasional

Menurut Kirkbride (2006:26) Indikator kunci dari motivasi inspirasional ini adalah :

1. Menunjukkan optimisme kepada bawahan terhadap visi yang bisa dicapai di masa yang akan datang

2. Membendung ekspektasi dan membentuk arti

3. memberikan kepercayaan dan tanggung jawab yang menginspirasi kayawan untuk bekerja dengan baik.

4. Menciptakan prioritas dan tujuan dengan jelas.

\section{METODE PENELITIAN}

Jenis penelitan yang digunakan pada penelitian ini adalah melalui analisis deskriptif dan verifikatif. Moh. Nazir (2003:54) mengemukakan bahwa metode deskriptif adala metode dalam meneliti status, sekelompok manusia, suatu objek, suatu kondisi, suatu sistem pemikiran ataupun suatu kelas peristiwa pada masa sekarang. Tujuan dari penelitian ini adalah membuat deskripsi, gambaran, atau lukisan secara sistematis, faktual dan akurat mengenai fakta-fakta, serta Pengaruh antara fenomena yang diselidiki. Dengan menggunakan metode ini maka dapat diperoleh deskripsi mengenai gambaran Pengaruh Kepemimpinan Transformasional terhadap kinerja karyawan di bidang sumber daya insani pada Rumah Sakit Muhammadiyah Bandung.

Sedangkan penelitian verifikatif menurut Suharmi Arikunto (2006:7) adalah penelitian yang pada dasarnya ingin menguji kebenaran melalui pengumpulan data di lapangan. Penelitian ini digunakan untuk menguji dari hipotesis melalui pengumpulan data di lapangan. Dalam hal ini akan dilakukan penyebaran angket (kuesioner) terhadap karyawan di bidang sumber daya insani pada Rumah Sakit Muhammadiyah Bandung.

Dalam penelitian verifikatif ini akan mengetahui apakah ada pengaruh yang siginifikan anatar Kepemimpinan Transformasional terhadap Kinerja Karyawan di Bidang Sumber Daya Insani pada Rumah Sakit Muhammadiyah Bandung.

\section{Teknik Pengumpulan Data}

Teknik pengumpulan data merupakan suatu cara yang digunakan untuk memperoleh data. Adapun teknik pengumpulan data yang digunakan dalam penelitian ini adalah sebagai berikut:

1. Studi kepustakaan (Library Research) : yaitu teknik pengumpulan data dengan mempelajari buku-buku, catatan serta literatur lain yang dapat dijadikan referensi yang berhubungan dengan objek penelitian.

2. Riset lapangan (Field Research) : yaitu dengan melaksanakan pengamatan langsung terhadap objek penelitian, diantranya dengan teknik:

a. Kuesioner (Angket)

Menurut Sugiyono (2017:142)

kuesioner adalah teknik pengumpulan data yang dilakukan dengan cara memberi seperangkat pertanyaan atau pernyataan tertulis kepada responden untuk dijawab. Kuesioner dapat berupa pertanyaan/ pernyataan tertutup atau terbuka, dapat diberikan 
kepada responden secara langsung atau dikirim melalui pos atau internet.

b. Wawancara

Wawancara yang dilakukan adalah wawancara tidak terstruktur, dimana peneliti tidak menggunakan pedoman wawancara yang telah tersusun sistematis dengan lengkap untuk pengumpulan data.

\section{Populasi penelitian}

Populasi adalah wilayah generalisasi yang terdiri atas; objek atau subjek yang mempunyai kuantitas dan karakteristik tertentu yang ditetapkan oleh peneliti untuk dipelajari dan kemudian ditarik kesimpulannya (Sugiyono, 2017:80). Populasi dari penelitian ini adalah Karyawan Bidang Sumber Daya Insani (SDI) Rumah Sakit Muhammadiyah Bandung yang berjumlah 32 orang.

Populasi dan sampling Menurut Sugiyono (2017:85) sampling jenuh adalah teknik penentuan sampel bila semua anggota populasi digunakan sebagai sampel. Hal ini sering dilakukan bila jumlah populasi relatif kecil, kurang dari 30 orang. Istilah lain sampel jenuh adalah sensus, dimana semua anggota populasi dijadikan sampel.

Sugiyono dan Hair (1998:123) berpendapat bahwa pada teknik sampel random sederhana (Simple Random Sampling), apabila subjek penelitian jumlahnya kurang dari 100 lebih baik diambil semua sehingga penelitiannya merupakan penelitian populasi.

\section{Uji Validitas}

Validitas adalah suatu ukuran yang menunjukkan tingkat kevalidan dan keshahihan atau keaslian suatu instrumen. Suatu instrumen yang valid atau sahih mempunyai validitas yang tinggi. Sedangkan instrumen yang kurang valid memiliki validitas yang rendah (Suhasimi Arikunto, 2010:211).

Uji validitas dilakukan untuk menguji sejauh mana item kuesioner yang valid dan mana yang tidak valid. Hal ini dilakukan dengan mencari korelasi setiap item pertanyaan dengan skor total pertanyaan untuk hasil jawaban responden yang mempunyai skala pengukuran ordinal. Rumus yang digunakan untuk menghitung kevalidan dari suatu instrumen adalah rumus Product Moment.

\section{Uji Realibilitas}

Uji reliabilitas dilakukan dengan menggunakan metode uji statistik Cronbach Alpha (koefisien alfa) dengan menggunakan program SPSS 13.0 Windows.

(Triton, 2006 dalam Sujianto, 2007), menyatakan bahwa jika skala itu dikelompokkan dalam 5 kelas dengan range yang sama, maka ukuran kemantapan alpha dapat diinterpretasikan sebagai berikut:

- Nilai Alpha Cronbach 0,00 s.d. 0,20 berarti tidak reliabel

- Nilai Alpha Cronbach 0,21 s.d. 0,40 berarti kurang reliabel

- Nilai Alpha Cronbach 0,41 s.d. 0,60 berarti cukup realibel

- Nilai Alpha Cronbach 0,61 s.d. $\mathbf{0 , 8 0}$ berarti reliabel

- Nilai Alpha Cronbach 0,81 s.d. 1,00 berarti Sangat realibel

Kuesioner dianggap valid dan realibel apabila nilai koefisien korelasi Product Moment hitung dan nilai koefisien korelasi Alpha Cronbach hitung lebih besar daripada nilai korelasi Product Moment tabel. 


\section{Analisis Regresi Sederhana}

Analisis regresi sederhana adalah teknik analisis yang meliputi metode - metode yang digunakan untuk memprediksi nilai-nilai dari satu atau lebih variabel tergantung yang dihasilkan adanya pengaruh satu atau lebih variabel bebas.

Dalam peneltian ini digunakan jenis analisis regresi sederhana. Menurut Sugiyono (2009:204), regresi sederhana didasarkan hubungan fungsional ataupun kausal satu variabel independen dengan satu variabel dependen. Persamaan umum regresi sederhana adalah:

\section{$\boldsymbol{Y}=\boldsymbol{a}+\boldsymbol{b} \boldsymbol{X}$}

Dimana:

$\mathrm{Y} \quad=$ subjek dalam variabel yang diprediksi

a = harga $\mathrm{Y}$ bila $\mathrm{X}=0$ (harga konstanta)

$\mathrm{b}=$ angka arah atau koefisien regresi yang menunjukkan angka peningkatan ataupun

penurunan variabel dependen yang didasarkan pada variabel independen. Bila b (+) maka naik dan bila (-) maka terjadi penurunan.

$\mathrm{X}=$ subjek pada variabel independen yang mempunyai nilai tertentu.

\section{Analisis Determinasi}

Koefisien Determinasi ini digunakan untuk mengukur seberapa besar pengaruh Kepemimpinan Transformasional terhadap kinerja karyawan. Koefisien determinasi dihitung dengna cara mengkuadratkan hasil korelasi kemudian dikalikan dengan $100 \%$ dengan menggunakan rumus sebagai berikut:

$$
d=r^{2} \times 100 \%
$$

sumber: Suharsimi Arikunto, 2010:144 sebelum nilai $r^{2}$ digunakan untuk membuat kesimpulan terlebih dahulu harus diuji apakah nilai-niali $\mathrm{r}^{2}$ ini terletak dalam daerah penerimaan atau penolakan Ho.

\section{Pengujian Hipotesis}

Untuk menguji apakah variabelvariabel koefisien regresi sederhana signifikan atau tidak, maka dilakukan pengujian melalui uji t.

a) Menentukan hipotesis

$\mathrm{H}_{0} \quad$ : Tidak ada pengaruh yang positif dan dengan Kinerja Karyawan.

$\mathrm{H}_{\mathrm{a}} \quad$ : Ada pengaruh yang positif dan signifi Kinerja Karyawan.

b) Menentukan tingkat signifikansi Tingkat signifikansi menggunakan $\alpha=5 \%$ (signifikansi $5 \%$ atau 0,05 adalah ukuran standar yang sering digunakan dalam penelitian).

c) Menentukan $t_{\text {hitung }}$

d) Menentukan $t_{\text {tabel }}$

Tabel distribusi t dicari pada $\alpha=5 \%$ dengan derajat kebebasan $(\mathrm{df})=\mathrm{n}-\mathrm{k}-1$

e) Kriteria Pengujian

Ho diterima jika $t_{\text {hitung }}<t_{\text {tabel }}$

Ho ditolak jika $t_{\text {hitung }}>t_{\text {tabel }}$

Membandingkan $t_{\text {hitung }}$ dengan $t_{\text {tabel }}$

\section{ANALISIS DATA DAN PEMBAHASAN \\ Uji Validitas dan Realibilitas}

Uji Validitas dan Reabilitas Instrumen pada penelitian ini dilakukan pada taraf signifikasi sebesar 5\%, dan seluruh proses Uji Validitas dan Realibilitas tersebut menggunakan program aplikasi SPSS versi 13 for windows. Sesuai dengan indikatorindicator variabel penelitian., maka kuesioner sebagai instrument pengukur variabel Kepemimpinan sejumlah 23 item pernyataan dan variabel Kinerja Karyawan berjumlah 16 item pernyataan. Hasil pengolahan SPSS 13 
For windows terhadap responden untuk variabel Kepemimpinan dapat dilihat pada lampiran.

Dapat diketahui dengan cara membandingkan nilai correlated item total pada output uji validitas variabel Kepemimpinan dengan nilai $\mathrm{r}$ product moment ( $r$ table) sebagai berikut:

$\mathrm{r}$ table pada tingkatan signifikansi $(\mathrm{dt}=$ $5 \%)=\mathrm{n}-2.5 \%=32-2.5 \%=0,3388$

Dasar pengambilan keputusan:

Jika correlated item total> $\mathrm{r}$ table, maka item tersebut valied

Jika correlated item total $<\mathrm{r}$ table, maka item tersebut tidak valid.

Berdasarkan langkah-langkah tersebut diatas, maka 23 item pernyataan untuk variabel Kepemimpinan dinyatakan 21 valid dan 2 item dinyatakan tidak valid. (dapat dilihat pada lampiran).

$$
\text { Selanjutnya dilakukan uji }
$$

realibilitas untuk kedua variabel tersebut dasar pengambilan keputusan dalam uji realibilitas sebagai berikut:

Jika nilai Cronbach's Alpha $>r$ tabel, maka variabel tersebut reliabel.

Jika nilai Cronbach's Alpha $<r$ tabel, maka variabel tersebut tidak reliabel.

Tabel 2. Uji Realibitas Variabel $X$ (Kepemimpinan)

Tabel 3. Uji Realibitas Variabel $Y$ (Kinerja Karyawan)

Reliability Statistics

\begin{tabular}{|l|l|}
\hline Cronbach's & N of Items \\
\hline
\end{tabular}

\begin{tabular}{|l|l|}
\hline Alpha & \\
\hline, 882 & 16 \\
\hline
\end{tabular}

Berdasarkan dasar keputusan diatas, maka variabel Kepemimpinan Transformasional dinyatakan realibel, karena nilai Cronbach's Alpha > r tabel yaitu $0,903>0,3388$ dapat dilihat pada lampiran. Dengan demikian juga untuk variabel Kinerja Karyawan responden dinyatakan realibel, karena memiliki nilai Cronbach's Alpha > r tabel yaitu $0,882>0,3388$ dapat dilihat pada lampiran.

\section{Karakteristik Responden}

- Karakteristik 32 responden berdasarkan jenis kelamin seluruhnya merupakan pria sebanyak 18 orang dan wanita 14 orang.

- Pendidikan terakhir responden, klasifikasi Pendidikan yang terbanyak adalah SMA sebanyak 13 orang. Responden yang menemuh Pendidikan D3 yaitu sebanyak 8 orang dan responden yang berpendidikan $\mathrm{S} 1$ ialah sebanyak 11 orang.

\section{Analisis Regresi Sederhana}

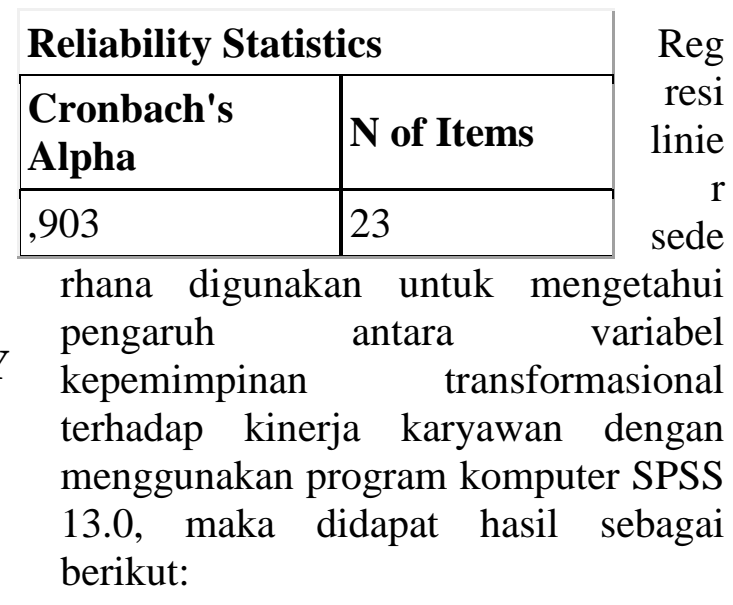


Table 4.Hasil Uji Regresi

\begin{tabular}{|c|c|c|c|c|c|c|}
\hline \multicolumn{7}{|c|}{ Coefficients(a) } \\
\hline \multirow[b]{2}{*}{ Model } & & \multicolumn{2}{|c|}{$\begin{array}{l}\text { Unstandardized } \\
\text { Coefficients }\end{array}$} & \multirow{2}{*}{\begin{tabular}{|l} 
Standardized \\
Coefficients
\end{tabular}} & \multirow[b]{2}{*}{$\mathbf{t}$} & \multirow[b]{2}{*}{ Sig. } \\
\hline & & B & $\begin{array}{l}\text { Std. } \\
\text { Error }\end{array}$ & & & \\
\hline \multirow{2}{*}{1} & (Constant) & 3,631 & 5,184 & &, 700 & ,489 \\
\hline & Kinerja_Karyawan & 1,300 &, 084 & ,943 & 15,524 &, 000 \\
\hline
\end{tabular}

a Dependent Variable: Gaya_Kepemimpinan_Trans

Berdasarkan tabel 4.5 diatas diketahui bahwa nilai koefisien dari persamaan regresi output didapatkan model persamaan regresi : $\mathrm{Y}=3,631+1,300 X$

Ket : $\quad \mathrm{Y}$ : Kinerja Karyawan

a : konstanta

b : koefisien Regresi

Transformasional

Kepemimpinan

Hasil persamaan regresi, nilai konstanta sebesar 3,631 artinya apabila tidak terdapat Kepemimpinan Transformasional dan Kinerja Karyawan $(\mathrm{X}=0)$ maka koefisien regresi kinerja karyawan sebesar 3,631. Koefisien regresi variabel kepemimpinan transformasional (X) sebesar 1,300 artinya jika kepemimpinan transformasional mengalami kenaikan 1 satuan nilai maka efektifitas kinerja karyawan (Y) akan mengalami peningkatan 1,300.
Dari perhitungan diatas menunjukkan bahwa koefisien regresi variabel kepemimpinan transformasional terhadap kinerja karyawan adalah sebesar 1,300. Angka ini bernilai sangat positif, artinya kedua variabel tersebut memiliki pengaruh yang searah. Ini menggambarkan bahwa kinerja karyawan bidang sumber daya insani pada Rumah Sakit Muhammadiyah Bandung dipengaruhi oleh kepemimpinan transformasional. Semakin baik program kepemimpinan transformasional yang diberikan, maka kinerja karyawan akan menjadi lebih baik lagi.

\section{Koefisien Determinasi}

Untuk mengetahui persentasi pengaruh variabel kepemimpinan transformasional terhadap variabel kinerja karyawan. Hasil koefisien determinasi yang telah diolah adalah sebagai berikut:

\section{Table 5.Hasil Koefisien Determinasi}

Model Summary(b)

\begin{tabular}{|c|c|c|c|c|c|c|c|c|c|}
\hline \multirow{2}{*}{$\begin{array}{l}\text { Mode } \\
\text { I }\end{array}$} & \multirow{2}{*}{$\mathbf{R}$} & \multirow{2}{*}{$\begin{array}{l}\text { R } \\
\text { Squar }\end{array}$} & \multirow{2}{*}{$\begin{array}{lr}\text { Adjuste } \\
\text { d }\end{array}$} & \multirow{2}{*}{$\begin{array}{l}\text { Std. } \\
\text { Error of }\end{array}$} & \multicolumn{5}{|c|}{ Change Statistics } \\
\hline & & & & & $\mathbf{R}$ & $\mathbf{F}$ & df & df & Sig. \\
\hline
\end{tabular}




\begin{tabular}{|c|c|c|c|c|c|c|c|c|c|}
\hline & & e & Square & $\begin{array}{l}\text { the } \\
\text { Estimat } \\
\text { e }\end{array}$ & $\begin{array}{l}\text { Square } \\
\text { Chang } \\
\mathrm{e}\end{array}$ & $\begin{array}{l}\text { Chang } \\
\text { e }\end{array}$ & 1 & 2 & $\begin{array}{l}\text { Chang } \\
\text { e }\end{array}$ \\
\hline 1 & ${ }^{943(\mathrm{a}}$ & ,889 &, 886 & 4,327 &, 889 & 240,993 & 1 & 30 &, 000 \\
\hline \multicolumn{10}{|c|}{ a Predictors: (Constant), Kinerja_Karyawan } \\
\hline \multicolumn{10}{|c|}{ b Dependent Variable: Gaya_Kepemimpinan_Trans } \\
\hline
\end{tabular}

Pada table di atas terlihat bahwa besarnya pengaruh antara Kepemimpinan Transformasional (X) dan Kinerja Karyawan (Y). Besarnya $r$ square adalah 0,889, artinya bahwa pengaruh variabel Kepemimpinan Transformasional terhadap variabel Kinerja Karyawan adalah sebesar $88,9 \%$, sedangkan sisanya sebesar $11,1 \%$ dipengaruhi oleh variabel lain yang tidak diteliti oleh peniliti.

\section{Pengujian Hipotesis}

Berdasarkan hasil uji statistik $\mathrm{t}$ pada tabel menunjukkan $t$ hitung untuk kepemimpinan transformasional sebesar 15,524. Besarnya $t$ hitung $\alpha=0,05$ adalah sebesar 2,022.

$15,524>2,022$ maka H0 ditolak, berarti Ha diterima artinya Variavel $\mathrm{X}$ dan Variabel $\mathrm{Y}$ ada pengaruhnya.

Diperoleh nilai signifikansi $0,000<0,05$. Dengan demikian dapat disimpulkan bahwa Kepemimpinan Transformasional berpengaruh positif dan terhadap Kinerja Karyawan.

\section{SIMPULAN DAN SARAN}

Kepemimpinan Transformasional Wakil Direktur pada Rumah Sakit Muhammadiyah Bandung dinyatakan dalam kategori Baik sesuai dengan persepsi karyawan. Adapun aspek yang paling tinggi yaitu pernyataan senantiasa merayakan keberhasilan bawahan dengan sangat baik. Namun dirasakan pula bahwa dalam hal mengenali pola yang sulit untuk dibayangkan oleh pemimpin masih belum optimal.

Persepsi responden tentang Kinerja Karyawan termasuk kategori baik. Adapun aspek yang paling tinggi yaitu pernyataan memiliki kepercayaan akan tanggungjawab dalam pekerjaan, sedangkan aspek yang paling rendah adalah dalam hal senantiasa bersedia untuk kerjasama dengan orang lain sesama anggota organisasi dirasa kurang optimal.

Pengaruh

Kepemimpinan Transformasional terhadap Kinerja Karyawan Bidang Sumber Daya Insani pada Rumah Sakit Muhammadiyah Bandung adalah ,889, artinya bahwa sumbangan pengaruh Kepemimpinan Transformasional terhadap Kinerja Karyawan adalah sebesar 88,9\%, sedangkan sisanya sebesar $11,1 \%$ dipengaruhi oleh variabel yang tidak diteliti dalam penelitian ini. Misalkan motivasi karyawan dan kompensasi.

Untuk meningkatkan Kepemimpinan, maka perusahaan harus lebih memperhatikan hal-hal yang berkaitan dengan Stimulasi Intelektual. Manajer harus memberikan perhatian dan stimulasi intelektual terhadap karyawan yang memiliki tanggungjawab kerja yang 
tinggi serta mengadakan program penghargaan kepada setiap karyawan yang berprestasi, serta memperbaiki aspek program pendidikan dan latihan bagi para karyawan.

Untuk meningkatkan kinerja Karyawan, maka perusahaan harus memberikan kondisi yang nyaman kepada karyawan dalam hal pekerjaan dan memberikan peluang kesetiap karyawan dalam proses interaksi serta membangun kerjasama. Disamping itu juga perusahaan disarankan untuk mengadakan program evaluasi secara berkala.

Untuk meningkatkan pengaruh pemimpin terhadap kinerja karyawan yang perlu diperhatikan hal yang akan memperbaiki kepemimpinan di Rumah Sakit Muhammadiyah Bandung, disamping itu juga harus diperhatikan agar kinerja karyawan meningkat misalkan mempertahankan kedisplinan dan kompensasi dengan program pendidikan dan latihan bagi karyawan.

\section{DAFTAR PUSTAKA}

Gomes, Faustino Cardoso. 2003. Manajemen Sumber Daya Manusia, Yogyakarta: Penerbit Andi

L. Mathis, Robet. H. Jackson, Jhon. 2006. Human Resource Management, Jakarta: Salemba Empat
Kirkbirde, Paul. 2006. Developing transformational leaders: the full range leadership model in action", Industrial and Commercial Training, Vol. 38 Issue: 1, pp.23-32, doi: 10.1108/00197850610646016

Sugiyono. 2009. Metode Penelitian Bisnis. Bandung: Alfabeta . 2017. Metode Penelitian Kuantitatif Kualitatif dan R\&D. Bandung: Alfabeta

Arikunto, Suharsimi. 2006. Prosedur Penelitian Suatu Pendekatan Praktik. Jakarta: Rineka Cipta.

Nazir, Mohammad. 2003. Metode Penelitian, Jakarta: Ghalia Indonesia.

Daft. L. Richard, Marcic Dorothy. Management: The New Workplace. Penerbit Thomson South Western, 2007.

Stoner. F.A. James. Management. Penerbit Prentice-Hall of India Privated Limited, 2006

Dessler. Gary, : Human Resource Management. Penerbit: Prentice Hall, 2011

Sumber Internet:

Consulting Firm Globaldi http//www.portalhr.com diakses tanggal $24 \quad$ Februari 2016. 